\title{
Allozyme variation among three populations of the armored catfish Hypostomus regani (Ihering, 1905) (Siluriformes, Loricariidae) from the Paraná and Paraguay river basins, Brazil
}

\author{
Cláudio H. Zawadzki, Erasmo Renesto, Maria Dolores Peres and Suzana Paiva \\ Departamento de Biologia, Núcleo de Pesquisas em Limnologia Ictiologia e Aqüicultura G-90, \\ Universidade Estadual de Maringá, Maringá, PR, Brazil.
}

\begin{abstract}
Three Brazilian populations of the armored catfish Hypostomus regani (Ihering, 1905) were sampled, one from the Corumbá Reservoir in Goiás state, another from the Itaipu Reservoir in Paraná state and a third from the Manso Reservoir in Mato Grosso state. Allozyme electrophoresis was used to establish the genetic structure of the species, with the analysis of liver, heart and muscles tissues allowing the scoring of 25 loci from 14 enzymatic systems. Although no diagnostic loci were found, some exclusive rare alleles were recorded for the three populations. The genetically most similar populations were those from Corumbá and Itaipu, and the most distant were the populations from Manso and Corumbá. The allozyme data showed three structured populations belonging to the same species $H$. $\operatorname{regani}\left(F_{S T}=0.173\right)$.
\end{abstract}

Key words: allozymes, genetic variability, Hypostomus regani, Loricariidae, Paraguay and Paraná Rivers.

Received: May 7, 2007; Accepted: December 12, 2007.

\section{Introduction}

Species of the armored catfish genus Hypostomus (Siluriformes, Loricariidae) feed mainly on rock bottoms by scraping the substratum (Delariva and Agostinho, 2001) and present the characteristics of benthonic and sedentary fish (Garavello and Garavello, 2004). These properties seem to be among the factors which have made Hypostomus one of the most speciose of the Neotropical genera, containing about 120 nominal species (Weber, 2003). The catfish Hypostomus regani (Ihering, 1905) is one of the most widespread species of the genus, ranging from the headwaters of the upper Paraná River basin in the Brazilian state of Goiás to the La Plata basin covering parts of Argentina, Brazil and Paraguay (Reis et al., 1990; Weber, 2003), also occurring in the Paraguay River basin. The wide geographical range of $H$. regani not only contrasts with the narrow distribution of most Hypostomus species but can also raise doubts about the conspecificity of $H$. regani populations. Studies of the genetic population structure of Neotropical fish have mainly focused on known migratory species such as Prochilodus lineatus

Send correspondence to Cláudio H. Zawadzki. Departamento de Biologia, Núcleo de Pesquisas em Limnologia Ictiologia e Aqüicultura G-90, Universidade Estadual de Maringá, Av. Colombo 5790, 87020-900 Maringá, PR, Brazil. E-mail: chzawadzki@ nupelia.uem.br.
(Characiformes, Prochilodontidae) (Revaldaves et al., 1997) and Pseudoplatystoma corruscans (Siluriformes, Pimelodidae) (Sekine et al., 2002), with studies on nonmigratory fish having been restricted to Hoplias malabaricus (Characiformes, Erythrinidae) (Dergam et al., 1998; Peres et al., 2002). We have no data about migratory behavior of $H$. regani, whether it is resident, short, medium or long distance migratory.

During the study described in this paper we used allozyme electrophoresis to investigate the genetic structuring of three geographically isolated Brazilian H. regani populations. The aim of the study was to estimate the genetic differentiation among the populations and verify if the fish in these populations belonged to the same species based on the presence of diagnostic loci that are fixed, or nearly fixed, for different alleles in two or more populations (Allendorf and Luikart, 2007) or a Nei's genetic identity below 0.80 (Thorpe, 1982).

\section{Material and Methods}

One of the Brazilian H. regani populations was collected in the Corumbá reservoir on the northern stretches of the Upper Paraná River basin in Goiás state (Figure 1), another was in the Itaipu reservoir in Paraná state, this reservoir constituting an ichthyofaunistic barrier splitting the Upper from the Medium Paraná River, while the third pop- 
ulation was from the Manso reservoir on the Manso River in the Paraguay River basin in Mato Grosso state. Hence these three populations were geographically isolated. Between April 1996 and February 2001 we collected 25 specimens from the Corumbá population (sampled at $17^{\circ} 59^{\prime} \mathrm{S}$, $48^{\circ} 31^{\prime} \mathrm{W}$; altitude $\left.571 \mathrm{~m}\right), 32$ from the Itaipu population $\left(25^{\circ} 21^{\prime} \mathrm{S}, 54^{\circ} 32^{\prime} \mathrm{W}\right.$; altitude $\left.218 \mathrm{~m}\right)$ and 33 from the Manso population (14 $52^{\prime} \mathrm{S}, 55^{\circ} 47^{\prime} \mathrm{W}$; altitude $277 \mathrm{~m}$ ). Voucher specimens of the $H$. regani populations sampled are deposited in the ichthyological collection at the Paraná State University at Maringá (Address: Núcleo de Pesquisas em Limnologia, Ictiologia e Aquicultura (Nupélia), Universidade Estadual de Maringá, PR, Brazil). The Accession numbers of the voucher specimens are NUP 2286 for the Corumbá material, NUP 2557 for the Itaipu material and NUP 3188 for the Manso material. This study was approved by the animal ethics committee of our institution and satisfied all requirements under Brazilian environmental laws. Sampling was carried out under permission of the Brazilian environmental agency (Instituto Brasileiro do Meio Ambiente e dos Recursos Naturais Renováveis IBAMA), protocol number 036/98 to Corumbá, 004/2001 to Itaipu, and 097 DIFAP/IBAMA to Manso samplings.

Heart, liver and white skeletal muscle samples were removed from the captured $H$. regani specimens and stored in liquid nitrogen until the moment of analysis. We analyzed the 14 enzymatic systems shown in Table S1. The electrophoretic procedures are detailed in Zawadzki et al. (1999). The nomenclature used for the loci and enzymes was proposed by Murphy et al. (1996). Alleles were designated with lower case letters in italics in ascending order of anodal mobility. The data were analyzed by the software

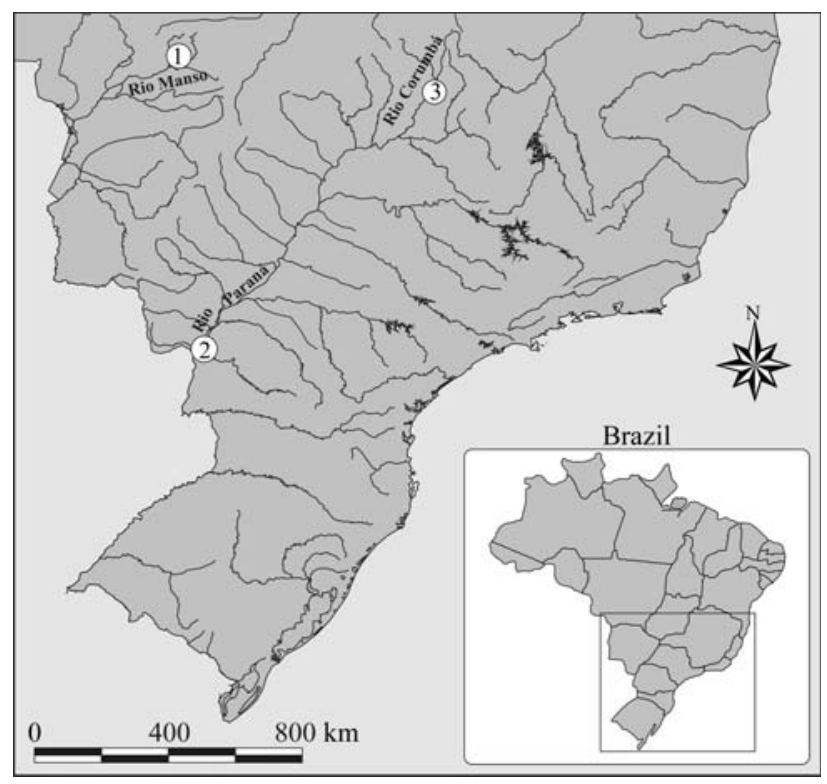

Figure 1 - Southern portion of South America showing the collection sites of Hypostomus regani from the Manso (1), Itaipu (2) and Corumbá reservoirs (3).
Biosys 1 (Swofford and Selander, 1981). Genetic structuring was appraised using Wright's F-statistic (Wright, 1978) and the significance tested by the chi-square $\chi^{2}$ test (Workman and Niswander, 1970). Genetic interpretation of the zymogram patterns was based on the quaternary structure of enzymes described by Ward et al. (1992). Genetic identity was assessed as the unbiased Nei's genetic identity (Nei, 1978).

\section{Results and Discussion}

For the 14 enzymatic systems analyzed in $H$. regani we detected 42 alleles in 25 loci, the tissue-specific expression patterns being similar to those found in Hypostomus myersi (Gosline, 1947) from the Iguaçu River, Brazil (Zawadzki et al., 2001). Table S2 shows the allele frequencies of the three populations analyzed. Single locus allele frequency heterogeneity was found for the following enzyme loci: $s$ Ata- $A\left(\chi^{2}=13.20, \mathrm{p}=0.0013\right)$; sAta-B $\left(\chi^{2}=50.62\right.$, $\mathrm{p}=0.0000) ; A d h-A\left(\chi^{2}=74.80, \mathrm{p}=0.0000\right) ;$ Gpi-B $\left(\chi^{2}=19.19, \mathrm{p}=0.00007\right) ; \operatorname{mIcdh}-A \quad\left(\chi^{2}=19.45\right.$, $\mathrm{p}=0.00006) ; s M d h-A\left(\chi^{2}=14.32, \mathrm{p}=0.0063\right)$; and Pgm- $A$ $\left(\chi^{2}=7.41, \mathrm{p}=0.0245\right)$. The three populations showed allele frequency heterogeneity for all analyzed loci $\left(\chi^{2}=214.946\right.$ for 34 degrees of freedom $(\mathrm{df}), \mathrm{p}=0.0000)$. Almost all polymorphic loci analyzed were in Hardy-Weinberg equilibrium (HWE). Loci not in HWE were $A c p-A$ for the Corumbá population, $s A a t-A$ and $s A a t-B$ for the Itaipu population and $G c d h-A$ and $I c d h-A$ for the Manso population. No diagnostic locus was found for these three populations. The estimated genetic variability for the three populations is shown in Table 1, with significant heterozygote deficiency being found in the Corumbá population, for which the inbreeding coefficient $\left(F_{I S}\right)$ was $0.180\left(\chi^{2}=4.50\right.$; $\mathrm{p}<0.05$. $)$, and Manso populations $\left(F_{I S}=0.274, \chi^{2}=9.05\right.$, $\mathrm{p}<0.05)$, but not in Itaipu population $\left(F_{I S}=0.090\right.$; $\left.\chi^{2}=2.89, \mathrm{p}>0.05\right)$. The unbiased Nei's genetic identity for the three populations is presented in Table S2. Genetic similarity was 0.989 between the Itaipu and Corumbá populations and 0.976 between the Corumbá and Manso populations. The Wright's F-statistics for all loci were different from zero, indicating an overall heterozygote deficiency. The estimated $F_{I S}$ value was $0.1419\left(\chi^{2}=12.77\right.$, $\mathrm{p}<0.001)$, the overall inbreeding coefficient $\left(F_{I T}\right)$ was $0.2902\left(\chi^{2}=104.47, \mathrm{p}<0.001\right)$, indicating heterozygote deficiency, and the relative genetic differentiation $\left(F_{S T}\right)$ was $0.1728\left(\chi^{2}=31.10, \mathrm{p}<0.001\right)$, which, taken together, indicates that the species was genetically structured in three populations. When the three populations were directly compared to each other the $F_{S T}$ values were significant and also indicated that the three populations were structured with $F_{S T}=0.0827$ for the Corumbá population $v s$. the Itaipu population, $F_{S T}=0.2139$ for the Corumbá population $v$. 
Table 1 - Allelic frequencies and genetic variability measures for three populations of Hypostomus regani from the Manso, Itaipu and Corumbá reservoirs. Numbers in bold type indicate exclusive alleles. $\mathrm{K}=$ mean number of alleles per locus; $\mathrm{P}_{0.99}=$ frequency of polymorphic loci; $H_{o}=$ mean observed heterozygosity; $H_{e}=$ mean expected heterozygosity. Numbers in parenthesis indicate the standard error.

\begin{tabular}{|c|c|c|c|c|}
\hline \multirow[t]{2}{*}{ Locus* } & \multirow[t]{2}{*}{ Allele } & \multicolumn{3}{|c|}{ Population } \\
\hline & & $\begin{array}{c}\text { Corumbá } \\
(\mathrm{n}=25)\end{array}$ & $\begin{array}{l}\text { Itaipu } \\
(\mathrm{n}=32)\end{array}$ & $\begin{array}{l}\text { Manso } \\
(\mathrm{n}=33)\end{array}$ \\
\hline \multirow[t]{3}{*}{$s A t a-A$} & $a$ & 0.040 & 0.016 & 0.015 \\
\hline & $b$ & 0.620 & 0.984 & 0.985 \\
\hline & $c$ & 0.340 & - & 0.985 \\
\hline \multirow[t]{2}{*}{$s A t a-B$} & $a$ & 1.000 & 0.891 & 1.000 \\
\hline & $b$ & - & 0.109 & - \\
\hline \multirow[t]{3}{*}{$A c p-A$} & $a$ & 0.060 & 0.016 & 0.015 \\
\hline & $b$ & 0.940 & 0.984 & 0.955 \\
\hline & $c$ & - & - & 0.030 \\
\hline \multirow[t]{2}{*}{$A d h-A$} & $a$ & 0.340 & 0.453 & 1.000 \\
\hline & $b$ & 0.660 & 0.547 & - \\
\hline \multirow[t]{2}{*}{ Gcdh-A } & $a$ & 1.000 & 1.000 & 0.970 \\
\hline & $b$ & - & - & 0.030 \\
\hline G3pdh-A & $a$ & 1.000 & 1.000 & 1.000 \\
\hline$G 3 p d h-B$ & $a$ & 1.000 & 1.000 & 1.000 \\
\hline G6pdh-A & $a$ & 1.000 & 1.000 & 1.000 \\
\hline G6pdh-B & $a$ & 1.000 & 1.000 & 1.000 \\
\hline \multirow[t]{3}{*}{ Gpi-B } & $a$ & 0.040 & 0.063 & - \\
\hline & $b$ & 0.940 & 0.938 & 1.000 \\
\hline & $c$ & 0.020 & - & - \\
\hline \multirow[t]{2}{*}{ Gpi-A } & $a$ & - & 0.156 & - \\
\hline & $b$ & 1.000 & 0.844 & 1.000 \\
\hline \multirow[t]{2}{*}{$m I c d h-A$} & $a$ & 0.960 & 0.625 & 0.818 \\
\hline & $b$ & 0.040 & 0.375 & 0.182 \\
\hline \multirow[t]{2}{*}{$s I c d h-A$} & $a$ & 1.000 & 1.000 & 0.970 \\
\hline & $b$ & - & - & 0.030 \\
\hline \multirow[t]{2}{*}{$L d h-B$} & $a$ & 0.020 & 0.047 & 0.030 \\
\hline & $b$ & 0.980 & 0.953 & 0.970 \\
\hline
\end{tabular}

\begin{tabular}{|c|c|c|c|c|}
\hline \multirow[t]{2}{*}{ Locus* } & \multirow[t]{2}{*}{ Allele } & \multicolumn{3}{|c|}{ Population } \\
\hline & & $\begin{array}{c}\text { Corumbá } \\
(\mathrm{n}=25)\end{array}$ & $\begin{array}{c}\text { Itaipu } \\
(\mathrm{n}=32)\end{array}$ & $\begin{array}{l}\text { Manso } \\
(\mathrm{n}=33)\end{array}$ \\
\hline$L d h-A$ & $a$ & 1.000 & 1.000 & 1.000 \\
\hline \multirow[t]{3}{*}{$s M d h-A$} & $a$ & - & - & 0.106 \\
\hline & $b$ & 1.000 & 0.984 & 0.894 \\
\hline & $c$ & - & 0.016 & - \\
\hline$m M d h-A$ & $a$ & 1.000 & 1.000 & 1.000 \\
\hline$s M d h-B$ & $a$ & 1.000 & 1.000 & 1.000 \\
\hline$s M d h p-A$ & $a$ & 1.000 & 1.000 & 1.000 \\
\hline$m M d h p-B$ & $a$ & 1.000 & 1.000 & 1.000 \\
\hline Per-1 & $a$ & 1.000 & 1.000 & 1.000 \\
\hline Per-2 & $b$ & 1.000 & 1.000 & 1.000 \\
\hline Per-3 & $c$ & 1.000 & 1.000 & 1.000 \\
\hline \multirow[t]{2}{*}{$P g m-A$} & $a$ & - & 0.063 & - \\
\hline & $b$ & 1.000 & 0.938 & 1.000 \\
\hline Sod-A & $a$ & 1.000 & 1.000 & 1.000 \\
\hline K & & $1.3(0.1)$ & $1.4(0.1)$ & $1.3(0.1)$ \\
\hline $\mathrm{P}_{0.99}$ & & 24.0 & 44.0 & 28.0 \\
\hline Ho & & $\begin{array}{l}0.0432 \\
(0.0224)\end{array}$ & $\begin{array}{l}0.0712 \\
(0.0238)\end{array}$ & $\begin{array}{l}0.0230 \\
(0.0110)\end{array}$ \\
\hline $\mathrm{He}$ & & $\begin{array}{l}0.0527 \\
(0.0269)\end{array}$ & $\begin{array}{l}0.0784 \\
(0.0251)\end{array}$ & $\begin{array}{l}0.0317 \\
(0.0124)\end{array}$ \\
\hline
\end{tabular}

*Key: Acp, acid phosphatase; Adh, alcohol dehydrogenase; Ata, aspartate transaminase; Gcdh, glucose 1-dehydrogenase - NAD+; G3pdh, glycerol-3-phosphate dehydrogenase; G6pdh, glucose-6-phosphate dehydrogenase; Gpi, glucose-6-phosphate isomerase; Icdh, isocitrate dehydrogenase - NADP+; $L d h$, L-lactate dehydrogenase; $M d h$, malate dehydrogenase; Mdhp, malate dehydrogenase - NADP+; Pgm, phosphoglucomutase; Per, peroxidase; and Sod, superoxide dismutase.

the Manso population and $F_{S T}=0.1270$ for the Itaipu population vs. the Manso population.

Our allozyme survey revealed high genetic differentiation in the three $H$. regani populations, with $F_{S T}$ values ranging from 0.0039 for the $L d h-B$ locus to 0.3454 for the $A d h-A$ and an average of $F_{S T}=0.1728(\mathrm{p}<0.001)$. These results show that $17.28 \%$ of the total heterozygosity was due to the population subdivision. Furthermore, the $\chi^{2}$ contingency test indicated that the three populations were very different $\left(\chi^{2}=214.946\right.$ for $\left.34 \mathrm{df}, \mathrm{p}<0.0001\right)$. According to Wright (1978), $F_{S T}$ values below 0.05 indicate low genetic differentiation, values from 0.05 to 0.15 moderate differentiation, values from 0.15 to 0.25 high differentiation and values above 0.25 very high differentiation. Nevertheless, the unbiased Nei's genetic distances indicated that the differences between the three populations analyzed were

within the limits of populations from the same species (Thorpe, 1982; Thorpe and Sole-Cava, 1994), indicating that they did indeed belong to the same species.

The genetic variability analysis revealed a variation in heterozygosity values among the three $H$. regani populations, but overall genetic variability $(0.065 \pm 0.012)$ was near the mean 0.051 for freshwater fish (Ward et al., 1992). The estimated expected heterozygosity $(\mathrm{He})$ for the Itaipu population was higher $(\mathrm{He}=0.0784)$ than for the Manso population $(H e=0.0527)$ or the Corumbá population $(\mathrm{He}=0.0317)$. Similar findings were reported by Zawadzki et al. (2002) for other Hypostomus species common to the Itaipu and Corumbá reservoirs. According to Zawadzki et al. (2005) the populations of Itaipu reservoir may have heterozygosity values increased by secondary contacts with populations from previously isolated tributaries that are 
now in contact due to the formation of Itaipu Lake in 1982, which flooded and covered the falls at the mouth of each tributary which probably used to act as a geographic barrier to free gene flow. On the other hand, the Corumbá River is a tributary of the Paranaíba, a river with a relative degree of fish endemism (Pavanelli and Britski, 1999), which may promote endogamy which in turn causes low heterozygosity.

Studies on fish population genetics have contributed to population management programs (Haig, 1998; SoleCava, 2001) and the detection of incipient ecological species (Dergam et al., 1998; Beheregaray and Sunnucks, 2001). In our present paper we have shown that the genetic distances between the different $H$. regani populations correlated with the geographic distance and river flow. However, caution is needed in the interpretation of these results because a study involving the mitochondrial genes ATPase 6 and ATPase 8 of Prochilodus lineatus from 13 localities from rivers of the Paraná-Paraguay basin did not produce genetic distance results corresponding to the geographic distances separating the localities (Sivasundar et al., 2001). McGlashan and Hughes (2000) also found no correlation between genetic and geographic distances when they used allozymes and the mitochondrial gene ATPase 6 to study Craterocephalus stercusmuscarum (Atheriniformes, Atherinidae) from northeastern Australia. Genetic differentiation among freshwater fish populations can be created not only by headwater captures, waterfall uplift and population distance which results in reduced gene flow (McGlashan and Hughes, 2000) but also by, differences in altitude, temperature, water velocity, food resources and reproductive strategies of which can lead to natural selection for local adaptations.

A highly important factor in the genetic differentiation of fish populations is the migratory capacity of a specific fish species, because the genetic structure of migratory fish exhibit less population differentiation than non-migratory fish. Marine fish populations have fewer barriers to gene flow and usually show less genetic differentiation than freshwater fishes (Gyllensten, 1985; Ward et al., 1994). Some migratory freshwater fish species such as $P$. lineatus (Revaldaves et al., 1997; Sivasundar et al., 2001) and $P$. corruscans (Sekine et al., 2002) show low genetic differentiation while poorly migratory or resident species such as $H$. malabaricus show high genetic differentiation (Dergam et al., 1998).

The Corumbá reservoir is about 1,110 kilometers from the Itaipu reservoir by river and several waterfalls used to naturally separate these two localities but some of these waterfalls have been eliminated by manmade reservoirs such as the Jupiá (flooded in 1974), Ilha Solteira (flooded in 1978) and São Simão (flooded in 1978) reservoirs. Furthermore, the Manso reservoir is about 4,400 from the Corumbá reservoir and 3,300 kilometers from the Itaipu reservoir by river, and hence we feel that the main reason for the high population differentiation of $H$. regani must be the natural barriers to gene flow in the localities surveyed.

\section{Acknowledgments}

The authors thank Horácio Ferreira Júlio Jr and Maria de Fátima P.S. Machado, for reviewing the manuscript. Édson K. Okada, João Dirço Latini, Samuel Veríssimo, and Wladimir M. Domingues for collecting samples. Núpelia, ITAIPU Binacional and FURNAS provided logistical support. This study partially supported by grants from the Brazilian agency Coordenação de Aperfeiçoamento de Pessoal de Nível Superior (CAPES).

\section{References}

Allendorf FW and Luikart G (2007) Conservation and Genetics of Populations. Blackwell, Malden, 642 pp.

Beheregaray LB and Sunnucks P (2001) Fine-scale genetic structure, estuarine colonization and incipient speciation in the marine silverside fish Odontesthes argentinensis. Mol Ecol 10:2849-2866.

Boyer SH, Fainer DC and Naughton MA (1963) Myoglobin inherited structural variation in man. Science 140:1228-1231.

Delariva RL and Agostinho AA (2001) Relationship between morphology and diets of six neotropical loricariids. J Fish Biol 58:832-847.

Dergam JA, Suzuki HI, Shibatta OA, Duboc LF, Júlio Jr HF, Giuliano-Caetano L and Black WC (1998) Molecular biogeography of neotropical fish Hoplias malabaricus (Erythriniade, Characiformes) in the Iguaçu, Tibagi and Paraná Rivers. Genet Mol Biol 21:493-496.

Garavello JC and Garavello JP (2004) Spatial distribution and interaction of four species of the catfish genus Hypostomus Lacépède with bottom of rio São Francisco, Canindé do São Francisco, Sergipe, Brazil (Pisces, Loricariidae, Hypostominae). Braz J Biol 64:591-598.

Gyllensten U (1985) The genetic structure of fish: Differences in intraspecific distribution of biochemical genetic variation between marine, anadromous, and freshwater species. J Fish Biol 26:691-699.

Haig SM (1998) Molecular contributions to conservation. Ecology 79:413-425.

McGlashan DJ and Hughes JM (2000) Reconciling patterns of genetic variation with stream structure, earth history and biology in the Australian freshwater fish Craterocephalus stercusmuscarum (Atherinidae). Mol Ecol 9:1737-1751.

Murphy RW, Sites JW, Buth DG and Haufler CH (1996) Proteins: Isozyme. Electrophoresis. In: Hillis DM, Moritz C and Mable BM (eds) Molecular Systematics. 2nd ed. Sinauer Associates, Massachusetts, pp 51-120.

Nei M (1978) Estimation of average heterozygosity and genetic distance from a small number of individuals. Genetics 89:583-590.

Pavanelli CS and Britski HA (1999) Description of a new species of Steindachnerina (Teleostei, Characiformes, Curimatidae) from the upper Rio Paraná basin, Brazil. Ichthyol Exp Fresh 10:211-216.

Peres DP, Renesto R, Lapenta AS and Zawadzki CH (2002) Genetic variability in Hoplias malabaricus (Osteichthyes, 
Erythrinidae) in fluvial and lacustrine environments in the upper Paraná river floodplain (Paraná State, Brazil). Biochem Genet 40:209-223.

Reis RE, Weber C and Malabarba LR (1990) Review of the genus Hypostomus Lacépède, 1803 from Southern Brazil, with descriptions of the three new species (Pisces, Siluriformes, Loricariidae). Rev Suisse Zool 97:729-766.

Revaldaves E, Renesto E and Machado MFPS (1997) Genetic variability of Prochilodus lineatus (Characiformes, Prochilodontidae) in the upper Paraná River. Braz J Genet 20:381-388.

Sekine ES, Prioli AJ, Prioli SMAP and Júlio Jr HF (2002) Genetic differentiation among Pseudoplatystoma corruscans (Agassiz, 1829) (Osteichthyes, Pimelodidae) isolated by the Guaíra Falls in the Paraná River. Acta Scient 24:507-512.

Shaw CR and Prasad R (1970) Starch gel electrophoresis - A compilation of recipes. Biochem Genet 4:297-320.

Sivasundar A, Bermingham E and Ortí G (2001) Population structure and biogeography of migratory freshwater fishes (Prochilodus, Characiformes) in major South American rivers. Mol Ecol 10:407-417.

Sole-Cava AM (2001) Biodiversidade molecular e genética da conservação. In: Matioli SR (ed) Biologia Molecular e Evolução. Holos, Ribeirão Preto, pp 173-192.

Swofford DL and Selander RB (1981) BIOSYS-1: A FORTRAN program for the comprehensive analysis of electrophoretic data in population genetics and systematics. J Hered 72:281-283.

Thorpe JP (1982) The molecular clock hypothesis: Biochemical evolution, genetic differentiation and systematics. Annu Rev Ecol Syst 13:139-168.

Thorpe JP and Solé-Cava AM (1994) The use of allozyme electrophoresis in invertebrate systematics. Zool Scripta 23:3-18.

Ward RD, Skibinski DOF and Woodward M (1992) Protein heterozygosity, protein structure, and taxonomic differentiation. Evol Biol 26:73-157.

Ward RD, Woodward M and Skibinski DOF (1994) A comparison of genetic diversity levels in marine, freshwater, and anadromous fishes. J Fish Biol 44:213-232.

Weber C (2003) The Hypostominae. In: Reis RE, Kullander SO and Ferraris Jr CJ (eds) Checklist of the Freshwater Fishes of
South and Central America. EDIPUCRS, Porto Alegre, pp 351-372.

Workman PL and Niswander JD (1970) Population studies on southwestern Indian tribes. II. Local genetic differentiation in the Papago. Am J Hum Gen 22:24-29.

Wright S (1978) Evolution and Genetics of Populations: Variability within and among Natural Populations. University of Chicago Press, Chicago, 465 pp.

Zawadzki CH, Renesto E and Bini LM (1999) Genetic and morphometric analysis of three species of the genus Hypostomus Lacépède, 1803 (Osteichthyes, Loricariidae) from the Rio Iguaçu basin (Brazil). Rev Suisse Zool 106:91-105.

Zawadzki CH, Reis RE and Renesto E (2000) Allozyme discrimination of three species of Loricariichthys (Siluriformes, Loricariidae) from Southern Brazil. Rev Suisse Zool 107:112.

Zawadzki CH, Machado MFPS and Renesto E (2001) Differential expression for tissue-specific isozymes in three species of Hypostomus Lacépède, 1803 (Teleostei, Loricariidae). Biochem Syst Ecol 29:911-922.

Zawadzki CH, Weber C, Pavanelli CS and Renesto E (2002) Morphological and biochemical comparison of two allopatrid populations of Hypostomus margaritifer (Regan, 1907) (Osteichthyes, Loricariidae) from the upper Paraná River basin, Brazil. Acta Scient 24:499-505.

Zawadzki CH, Renesto E, Reis RE, Moura MO and Mateus RP (2005) Allozyme relationships in hypostomines (Teleostei, Loricariidae) from the Itaipu Reservoir, upper Rio Paraná basin, Brazil. Genetica 123:271-283.

\section{Supplementary Material}

The following online material is available for this article:

- Table S1. Enzyme systems.

- Table S2. Genetic identity.

This material is made available as part of the online article from http://www.scielo.br.gmb Associate Editor: João S. Morgante

License information: This is an open-access article distributed under the terms of the Creative Commons Attribution License, which permits unrestricted use, distribution, and reproduction in any medium, provided the original work is properly cited. 
Table S1. Names, enzyme commission number (E.C. $n^{\circ}$.), tissues, buffers, quaternary structure (Q.S.) and number of loci for each enzyme detected in Hypostomus regani from the Corumbá, Itaipu and Manso reservoirs. $\mathrm{L}=$ liver; $\mathrm{M}=$ muscle; $\mathrm{H}=$ Heart; TBE = Tris/borate/EDTA $(\mathrm{pH}$ 8.7) (Boyer et al., 1963); TC = Tris/citrate (pH 7.0) (Shaw and Prasad, 1970). +

\begin{tabular}{llllll}
\hline Enzyme (Abbreviation) & E.C. $\mathbf{n}^{\mathbf{0}}$ & Tissue & Buffer & Q. S. & Loci \\
\hline Acid phosphatase (Acp) & 3.1 .3 .2 & L & TC & Dimeric & 1 \\
Alcohol dehydrogenase (Adh) & 1.1 .1 .1 & L & TBE & Dimeric & 1 \\
Aspartate transaminase (Ata) & 2.6 .1 .1 & L, H, M & TBE & Dimeric & 2 \\
Glucose 1-dehydrogenase - NAD+ (Gcdh) & 1.1 .1 .118 & L & TBE & Dimeric & 1 \\
Glycerol-3-phosphate dehydrogenase (G3pdh) & 1.1 .1 .8 & L, H, M & TC & Dimeric & 2 \\
Glucose-6-phosphate dehydrogenase (G6pdh) & 1.1 .1 .49 & L & TBE & Tetrameric & 2 \\
Glucose-6-phosphate isomerase (Gpi) & 5.3 .1 .9 & L, H, M & TC & Dimeric & 2 \\
Isocitrate dehydrogenase - NADP+ (Icdh) & 1.1 .1 .42 & L, H, M & TC & Dimeric & 2 \\
L-Lactate dehydrogenase (Ldh) & 1.1 .1 .27 & H, M & TC & Tetrameric & 2 \\
Malate dehydrogenase (Mdh) & 1.1 .1 .37 & L, H, M & TC & Dimeric & 3 \\
Malate dehydrogenase - NADP+ (Mdhp) & 1.1 .1 .40 & L, H, M & TC & Tetrameric & 2 \\
Phosphoglucomutase (Pgm) & 5.4 .2 .2 & L, H, M & TC & Monomeric & 1 \\
Peroxidase (Per) & 1.11 .1 .6 & L, H & TC & Tetrameric & 3 \\
Superoxide dismutase (Sod) & 1.15 .1 .1 & L, H, M & TBE & Dimeric & 1 \\
\hline
\end{tabular}


Table S2. Nei's unbiased genetic identity $(I)$ is shown in the upper diagonal and genetic distance $(D)$ in the lower diagonal for the three Hypostomus regani populations from the Corumbá, Itaipu and Manso reservoirs.

\begin{tabular}{lccc}
\hline Population & Corumbá & Itaipu & Manso \\
\hline Corumbá & ---- & 0.989 & 0.976 \\
Itaipu & 0.011 & ---- & 0.984 \\
Manso & 0.024 & 0.016 & ---- \\
\hline
\end{tabular}

